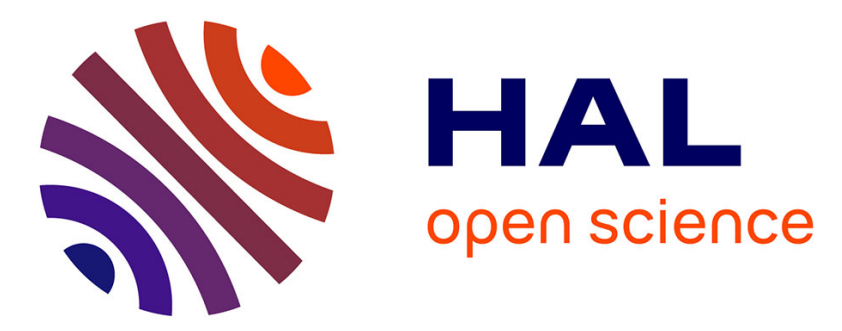

\title{
Systematic molecular and cytogenetic screening of 100 patients with marfanoid syndromes and intellectual disability
}

\author{
P. Callier, B. Aral, N. Hanna, S. Lambert, H. Dindy, C. Ragon, M. Payet, \\ Gwenaëlle Collod-Béroud, V. Carmignac, M. A. Delrue, et al.
}

\section{To cite this version:}

P. Callier, B. Aral, N. Hanna, S. Lambert, H. Dindy, et al.. Systematic molecular and cytogenetic screening of 100 patients with marfanoid syndromes and intellectual disability. Clinical Genetics, 2013, 84 (6), pp.507-521. 10.1111/cge.12094 . hal-01068032

\section{HAL Id: hal-01068032 \\ https://hal.science/hal-01068032}

Submitted on 20 Dec 2017

HAL is a multi-disciplinary open access archive for the deposit and dissemination of scientific research documents, whether they are published or not. The documents may come from teaching and research institutions in France or abroad, or from public or private research centers.
L'archive ouverte pluridisciplinaire HAL, est destinée au dépôt et à la diffusion de documents scientifiques de niveau recherche, publiés ou non, émanant des établissements d'enseignement et de recherche français ou étrangers, des laboratoires publics ou privés. 


\section{Systematic molecular and cytogenetic screening of 100 patients with marfanoid syndromes and intellectual disability}

Callier P, Aral B, Hanna N, Lambert S, Dindy H, Ragon C, Payet M, Collod-Beroud G, Carmignac V, Delrue MA, Goizet C, Philip N, Busa T, Dulac Y, Missotte I, Sznajer Y, Toutain A, Francannet C, Megarbane A, Julia S, Edouard T, Sarda P, Amiel J, Lyonnet S, Cormier-Daire V, Gilbert B, Jacquette A, Heron D, Collignon P, Lacombe D, Morice-Picard F, Jouk PS, Cusin V, Willems M, Sarrazin E, Amarof K, Coubes C, Addor MC, Journel H, Colin E, Khau Van Kien P, Baumann C, Leheup B,

Martin-Coignard D, Doco-Fenzy M, Goldenberg A, Plessis G, Thevenon J, Pasquier L, Odent S, Vabres P, Huet F, Marle N, Mosca-Boidron AL, Mugneret F, Gauthier S, Binquet C, Thauvin-Robinet C, Jondeau G, Boileau C, Faivre L.

The association of marfanoid habitus (MH) and intellectual disability (ID) has been reported in the literature, with overlapping presentations and genetic heterogeneity. A hundred patients (71 males and 29 females) with a $\mathrm{MH}$ and ID were recruited. Custom-designed 244K array-CGH (Agilent ${ }^{\circledR}$; Agilent Technologies Inc., Santa Clara, CA) and MED12, ZDHHC9, UPF3B, FBN1, TGFBR1 and TGFBR2 sequencing analyses were performed. Eighty patients could be classified as isolated $\mathrm{MH}$ and ID: 12 chromosomal imbalances, 1 FBN1 mutation and 1 possibly pathogenic MED12 mutation were found (17\%). Twenty patients could be classified as ID with other extra-skeletal features of the Marfan syndrome (MFS) spectrum: 4 pathogenic FBN1 mutations and 4 chromosomal imbalances were found ( 2 patients with both FBN1 mutation and chromosomal rearrangement) (29\%). These results suggest either that there are more loci with genes yet to be discovered or that MH can also be a relatively non-specific feature of patients with ID. The search for aortic complications is mandatory even if $\mathrm{MH}$ is associated with ID since FBN1 mutations or rearrangements were found in some patients. The excess of males is in favour of the involvement of other X-linked genes. Although it was impossible to make a diagnosis in $80 \%$ of patients, these results will improve genetic counselling in families.

\section{Conflict of interest}

The authors declare no conflict of interest.

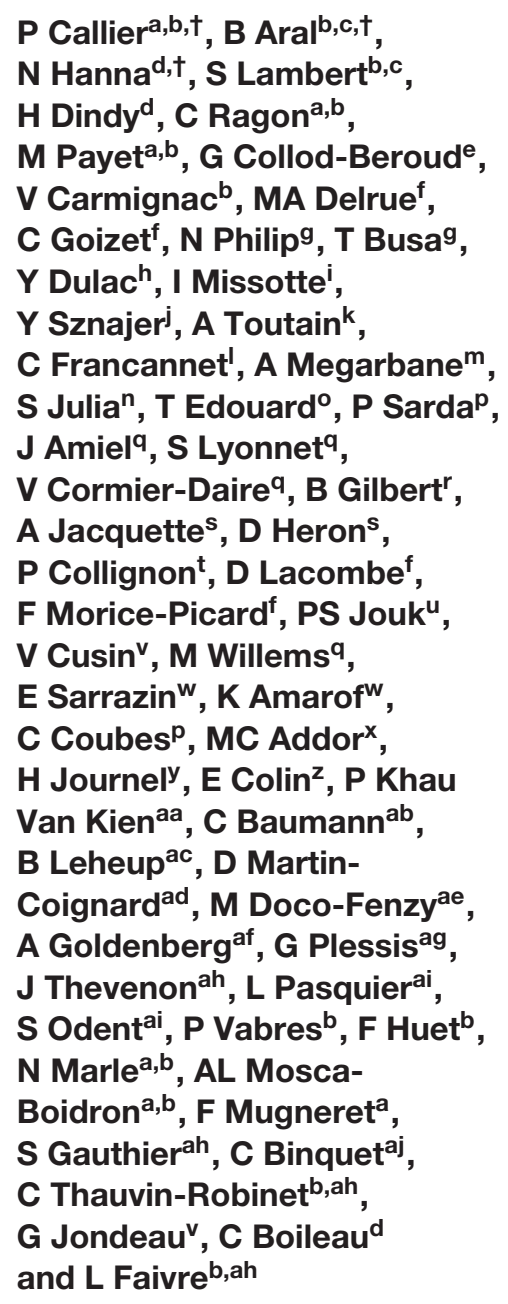

aservice de Cytogénétique, Plateau technique de Biologie, CHU, Dijon,

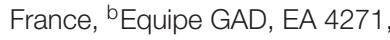
Université de Bourgogne, Dijon, France, 'Laboratoire de Biologie Moléculaire, Plateau technique de Biologie, $\mathrm{CHU}$, Dijon, France, dAPHP, Laboratoire de Biochimie et de Génétique moléculaire, Hôpital Ambroise Paré, Boulogne, France, ${ }^{~}$ INSERM, UMR_S 910, Marseille, F-13000, France, 'Département de Génétique, CHU Bordeaux et Université 
de Bordeaux, Bordeaux, France,

gDépartement de Génétique, Assistance Publique Hôpitaux de Marseille, Marseille,

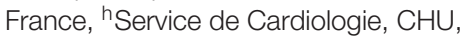
Toulouse, France, 'Service de Pédiatrie, Centre Hospitalier Territorial, Nouvelle Calédonie, France, 'Service de Génétique, CHU, Louvain, Belgique, France, ${ }^{k}$ Service de Génétique, CHU, Tours, France, 'Service de Génétique, $\mathrm{CHU}$, Clermont-Ferrand, France, mUnité de Génétique Médicale, Faculté de Médecine, Université Saint Joseph, Beirut, Lebanon, "nService de Génétique, $\mathrm{CHU}$, Toulouse, France, ${ }^{\circ}$ Service de Pédiatrie, CHU, Toulouse, France,

pService de Génétique, CHU, Montpellier, France, aDépartement de Génétique, Hôpital Necker-Enfants Malades, Paris, France, 'Génétique Médicale, $\mathrm{CHU}$, Poitiers, France, 's Département de Génétique, Hôpital Pitié Salpétrière, Paris, France, ' Service de Génétique Médicale, CH Font Pré, Toulon, France, "Service de Génétique Médicale, $\mathrm{CHU}$, Grenoble, France, ${ }^{v}$ Centre de Référence Maladie de Marfan, Hôpital Bichat, Paris, France, ${ }^{w}$ Centre de Référence Caraibeen des Maladies Rares Neurologiques et Neuromusculaires, $\mathrm{CHU}$ de Fort de France, Hôpital Pierre Zobda-Quitman, La Martinique, France, ${ }^{\times}$Service de Génétique Médicale, Centre Hospitalier Vaudois, Lausanne, Switzerland, 'YService de Génétique Médicale, $\mathrm{CH}$, Vannes, France, ${ }^{\mathrm{Z}}$ Département de Génétique, $\mathrm{CHU}$, Angers, France, aaservice de Biologie Moléculaire, $\mathrm{CHU}$, Montpellier, France, abService de Génétique Médicale, Hôpital Robert Debré, Paris, France, ${ }^{a c}$ Département de Génétique, $\mathrm{CHU}$, Nancy, France, ad Service de génétique Médicale, $\mathrm{CH}$, Le Mans, France, ${ }^{a}$ Département de Génétique et Centre de Référence Maladies Rares 'Anomalies du Développement et Syndromes Malformatifs' de la région Est, CHU Reims et EA3801 SFR Cap-Santé,

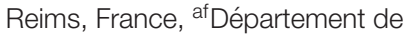
Génétique, $\mathrm{CHU}$, Rouen, France, agService de Génétique, $\mathrm{CHU}$, Caen, France, ${ }^{\text {ah }}$ Centre de Génétique et Centre de Référence Anomalies du Développement et Syndromes Malformatifs, Hôpital d'Enfants, Dijon,

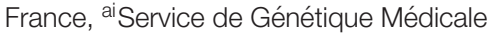
et Centre de Référence Anomalies du Développement de l'Ouest, $\mathrm{CHU}$, Rennes, France, and aj Centre d'Investigation Clinique - Epidémiologie Clinique, $\mathrm{CHU}$, Dijon, France

†These authors equally contributed to the work. 


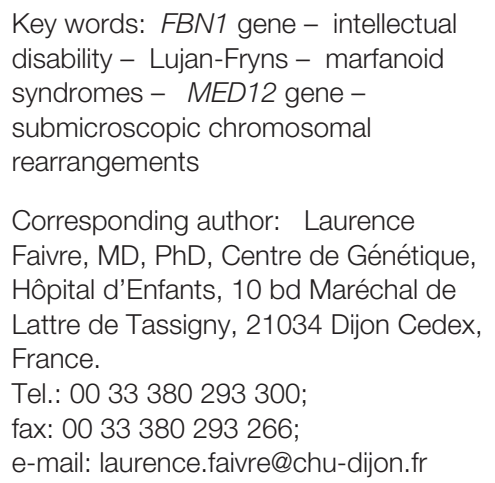

Marfan syndrome (MFS) is a multisystem genetic disease that can affect the cardiovascular, skeletal, ophthalmic, and integumentary systems and the dura mater. The diagnosis is based on an international classification $(1-3)$. The severity of the condition lies in the risk of dilation and subsequent dissection of the ascending aorta. The FBN1 gene is the major gene in patients with MFS, and variable expression of the disease has been largely identified within and between families $(4,5)$. Patients with atypical presentations not fulfilling the criteria involving only one organ system exist but are rare (6). Patients with MFS do not usually present with intellectual disability (ID) (7). Patients with MFS can also display mutations in the TGFBRI and TGFBR2 genes (8).

The term marfanoid habitus $(\mathrm{MH})$ is used to describe patients with skeletal signs suggestive of MFS but who do not meet the international criteria $(5,7)$. The association of a MH and ID has been reported in the literature in syndromes with overlapping features. ID is defined, according to the American Association of Intellectual and Developmental Disabilities as significant limitations both in intellectual functioning (referring to general mental capacity such as learning, reasoning, and problem solving) and in adaptative behaviour (comprising conceptual, social and practical skills), and originates before the age of 18. Its incidence is 1.26/100 (9). The Lujan-Fryns syndrome (LJS) was first described in male patients with a family history suggesting an X-linked mode of inheritance $(10,11)$. The term LJS is now recognized to describe patients with MH (long, hyperlax fingers and toes, tall stature, dolichostenomelia), facial dysmorphism (prominent forehead contrasting with a long, narrow face, maxillary hypoplasia, small mandible, long nose with a high narrow nasal root); mild to moderate ID with behavioural abnormalities, that could include emotional instability, shyness, or even psychotic disturbances, generalized hypotonia, nasal speech, normal development of sexual features $(12,13)$. This syndrome has also been reported occasionally in females $(14,15)$. Thoracic aortic aneurysm (TAA) is usually absent, but has been reported in two families, including one patient who required aortic surgery $(16,17)$. In 2007, the systematic screening of 737 genes annotated in the Vertebrate Genome Annotation database on the human chromosome $\mathrm{X}$ in 250 families with syndromic or non-syndromic X-linked ID led to the identification of hemizygous mutations in the MED12, ZDHHC9, and $U P F 3 B$ genes in a very small number of familial cases (18-20). The MED12 gene (MIM 300188, also called HOPA or TRAP230), located in Xq13, encodes for a subunit of the macromolecular complex known as Mediator, which is required for thyroid hormonedependent activation and repression of transcription by RNA polymerase II (21). Med12-deficient zebra fish embryos show defects in the brain and neural crest and do not survive beyond 1 week after fertilization (22). MED12 mutation have been found in only one large family with LJS, which was the index family reported by Lujan, and carrier females displayed no bias in chromosome $\mathrm{X}$ inactivation $(11,19)$. Mutations in the ZDHHC9 gene (MIM 300646, zinc finger, and DHHCtype containing 9), located in Xq26.1, have been found in three families with LJS (18). It encodes a palmitoyl transferase, highly expressed in the brain, which catalyzes the post-translational modification of rat sarcoma viral oncogene homolog (RAS). The mechanism by which loss of function mutations of $\mathrm{ZDHHC} 9$ lead to ID is unclear, but it may be through alteration of the relative proportion of the RAS proteins within the different compartments of nerve cells (23). Finally, mutations of the UPF3B gene (MIM 200298), located on Xq24, have been found in two families with LJS (20). The UPF3B protein is an important component of the nonsensemediated mRNA decay surveillance machinery (24) and the mechanism by which loss of function mutations of $U P F 3 B$ lead to ID is also unknown. Mutations of these three genes have also been found in patients with Opitz-Kaveggia (FG) syndrome $(18,20,25)$ and in non-syndromic ID for $U P F 3 B$ (20). These results have not been replicated to date in LJS.

ID and $\mathrm{MH}$ can also be found in Shprintzen-Goldberg syndrome (SGS) associated with 
craniosynostosis $(26,27)$ and rare de novo mutations have been described in the FBN1 or TGFBR2 genes. These results are still a subject of debate in the literature (28-30). ID is only reported very occasionally in Loeys-Dietz syndrome (LDS), secondary to mutations in the TGFBR1 and TGFBR2 genes (31). Finally, chromosomal imbalances have also been reported in sporadic observations, including one $15 \mathrm{q} 21.1 \mathrm{q} 21.3$ deletion involving the FBN1 gene (32) and two cases of terminal deletion of chromosome $5 p(33,34)$.

Therefore, the genetic aetiology of the association of a $\mathrm{MH}$ and ID represents a true challenge for individual diagnosis, follow-up and genetic counselling, particularly for sporadic presentations. Besides the clinical overlap between these different entities, the implication of each gene and its clinical spectrum in such a phenotype is unknown and little is known about the risk of aortic involvement. The aim of this research project was to conduct a clinical, cytogenetic and molecular study of a large cohort of 100 probands presenting with a skeletal marfanoid phenotype and ID, in order to provide answers to these questions, and help in the management of these patients.

\section{Materials and methods}

\section{Patients}

This study was prospectively designed. Patients were included by a clinical geneticist over an 18 months period. Inclusion criteria were the presence of ID and certain skeletal features of the Marfan spectrum, including at least two of the following clinical signs: height greater than the 97th centile in the absence of tall stature in parents, long, thin habitus, long, thin fingers, pectus abnormalities, and dolichostenomelia. A cardiac ultrasound and anterior eye chamber examination were required for all patients. The presence of heart and eye manifestations of the Marfan spectrum was not an exclusion criterion. Neuropsychological examination in order to evaluate non-subjectively the degree of ID could be performed in $15 \%$ of the patients only. In the other cases, ID was graduated according to the geneticist experience. Patients with a family history of MFS without ID were excluded from the study because the segregation was in favour of a different cause for $\mathrm{MH}$ and ID, and homocystinuria also needed to be ruled out. Inclusion was validated also after standard karyotype and FMRI gene study (Fragile-X) did not show any anomaly, although patients with apparently balanced chromosomal rearrangements were not excluded. Patients with the MH and ID were mainly recruited through the network of reference centres for rare diseases in France. Informed consent was obtained for all patients and the study was approved by the local ethics committee.

A detailed clinical evaluation was performed for every patient during a specialized consultation, and a detailed clinical file specifically designed for this project was completed by the referring geneticist, describing the family history, clinical features of
MFS and information regarding developmental data. Patients were divided into two groups, depending on the absence (group 1) or presence (group 2) of associated features characteristic of MFS (TAA, mitral valve prolapse or ectopia lentis). The median systemic score was calculated in the total cohort and among groups, according to the 2010 new Ghent criteria for the diagnosis of MFS and related disorders. A systemic score above 7 indicated systemic involvement (3).

\section{Molecular and cytogenetic analyses}

For etiological purposes, all patients were screened for mutations of the ZDHHC9, UPF3B, MED12, $T G F B R 1$, TGFBR2, and FBN1 genes and for chromosomal micro-rearrangements using $244 \mathrm{~K}$ custom microarray. Female patients were also screened for Xinactivation bias.

\section{Direct sequencing of ZDHHC9, UPF3B, MED12, FBN1,} TGFBR1 and TGFBR2 genes

Genomic DNA was extracted from blood samples of the patients and parents when available. Exons and exon-intron boundaries sequencing analyses of the MED12, ZDHHC9, UPF3B, FBN1, TGFBR1 and $T G F B R 2$ genes were performed according to previously reported methods $(8,18,20,35,36)$. Corresponding reference of the genomic DNA sequences were downloaded using Ensembl Genome Browser, www.ensembl.org. Sequence analyses were searched for between consensus and reference sequences using SEQSCAPE ${ }^{\circledR}$ software v2.5 package (Applied Biosystems, Foster City, CA). Mutation nomenclature numbering was based on the current Ensembl transcript (http://www.hgvs.org). The pathogenic nature of a mutation was determined according to a database search, bioinformatic predictions and segregation of the mutation in the family. The Universal Mutation Database (UMD) was used for FBN1 (37) and TGFBR2 (38) requests. When a mutation was suspected to lead to the creation of a splice site, additional mRNA studies were performed. All patients were screened for MED12, ZDHHC9, UPF3B, FBN1 and TGFBR2 gene mutations. Only patients with TAA were screened for TGFBR1 mutations.

\section{$X$-inactivation assay in female patients}

This assay was performed as previously reported (39) with some slight modifications, notably the use of fluorescent primers and the detection mode. A control was used in the analyses. X-inactivation assay in female patients was considered as biased when it was superior or equal to $85 \%$, or even $95 \%$.

\section{Array-CGH experiments}

A custom-designed array was designed with approximately 240,000 oligonucleotides manufactured by Diagnogene $^{\mathrm{TM}}$ (Division Imaxio, Biopôle SaintBeauzire, France). This array contains oligonucleotides 
selected from the Agilent online library (earray; https://earray.chem.agilent.com/earray) and has been further empirically optimized. In addition, we increased probe density within seven selected genes (12,307, Table S1). The entire genome was covered with an average resolution of $20 \mathrm{~kb}$ (NCBI, hg 18). The procedures of array-CGH were performed according to the Agilent instructions with minor modifications (40). Slides were scanned using the Agilent G2565 Microarray scanner and images quantified using AgIlent FeAture EXtraction (v9.0) and a graphical overview was obtained using GENOMIC WORKBENCH software (v5.0). Mapping data were analysed on the human genome sequence using Ensembl (www.ensembl.org; hg18). Copy Number Variations were assessed in the Database of Genomic Variants (http://projects.tcag.ca/variation/). When a chromosomal imbalance was detected, quantitative polymerase chain reaction (qPCR) or fluorescence in situ hybridization (FISH) studies with probes derived from bacterial artificial chromosomes were performed in order to confirm the chromosomal imbalances, as well as the family segregation. When a chromosomal imbalance was suspected to be pathogenic, the gene content was determined in order to find candidate genes for the phenotype, with a particular interest for genes expressed in the central nervous system and connective tissues (http://www.ensembl.org/biomart/). We also checked if a known 'microdeletion/microduplication syndrome' was described through the decipher database (http://sanger.ac.uk) and the available literature, and if additional patients with a similar phenotype had already been reported/gathered.

\section{Results}

\section{Patients}

Among the 100 patients with marfanoid phenotype and ID, 71 were males and 29 females (sex ratio: 2.45), originating from 98 families. They were aged from 2 to 45 years with a mean of $19.1 \pm 8.6$ years. Fifty percent of patients were adults. A family history of ID was found in 23/98 families, including $48 \%$ in a first-degree relative $(91 \%$ in a sibling and $9 \%$ in a parent), $17 \%$ in a second-degree relative (including $50 \%$ compatible with an X-linked inheritance) and $35 \%$ in other degrees (including $12 \%$ compatible with an $\mathrm{X}$-linked inheritance). $\mathrm{MH}$ was associated with ID in only four familial cases. Two patients had apparently balanced de novo reciprocal translocations: $\mathrm{t}(12 ; 19)(\mathrm{q} 13.3 ; \mathrm{p} 12)$, and $\mathrm{t}(2 ; 22)(\mathrm{q} 33 ; \mathrm{q} 11.2)$.

Detailed description of the overall cohort is given in Table 1. A minority was screened for dural ectasia and protrusio acetabulae. Other miscellaneous features included nasal speech $(n=18)$, abnormal genitalia $(n=15)$, ptosis $(n=5)$, vertebral instability $(n=4)$, deafness $(n=3)$, hypertrophic cardiomyopathy $(n=2)$, pneumothorax $(n=1)$, atrial septal defect $(n=1)$, aneurysm of the interventricular septum $(n=1)$, cleft lip $(n=1)$, absent uvula $(n=1)$, optic nerve atrophy $(n=1)$, horseshoe kidney $(n=1)$ and supernumerary mammary $(n=1)$.

General clinical, molecular and cytogenetic characteristics of patients belonging to group 1 and 2 are presented in Table 1. Clinical details of patients with a molecular or cytogenetic abnormality are presented in Tables 2-4. The systemic score for patients with a positive cytogenetic or molecular result was not significantly different from patients with normal results (7.6 $\pm 3.2 v s 6.6 \pm 2.9$ ).

\section{Molecular and cytogenetics results}

\section{FBN1 sequencing analysis}

Five pathogenic FBN1 mutations were found, one splicing and four missense mutations (Table 2). Their pathogenicity was verified according to the UMDpredictor tool (41) and except the c. $2534 \mathrm{G}>\mathrm{A}$ mutation (p.Cys845Tyr), they had already been reported at least once in the literature. Interestingly, the c. $4270 \mathrm{C}>\mathrm{G}$ (p.Pro1424Ala) mutation was found in two unrelated patients with no aortic manifestation at 18 and 36 years. The segregation of the mutation could not be verified in either family. The mutation had already been reported in six other instances in the UMD-FBN1 database (8, 42-46), and no ID was noticed when clinical data were available. The pathogenic nature of the FBN1 c.8176C $>$ T (p.Arg2726Trp) mutation in exon 64 was demonstrated by in vitro studies (47) and reported in a few instances in patients with isolated skeletal features and even incomplete penetrance (48). Within the UMD-FBN1 database, we found 11 families with this mutation, and aortic dilatation was reported in two patients $(37,49)$. The mutation was also found in the father and sister of the proband. When re-examined, they displayed some very mild skeletal features of the Marfan spectrum, including dolichostenomelia, arachnodactyly, high arched palate, dental crowding and myopia in the father, as well as dolichostenomelia, mild scoliosis, significant striae and high arched palate in the sister. The presence of ID in the proband was finally explained by the co-occurrence of a FBN1 mutation and a $17 \mathrm{q} 21.31$ microdeletion.

Four variants were considered as polymorphic or probably non-pathogenic, according to UMD-FBN1 predictor and segregation analyses (Table S2). Of note, although considered a polymorphism in this study, the c.6700G $>$ A (p.Val2234Met) variant was considered pathogenic in various publications $(45,50)$. Additional investigations were necessary to draw conclusions regarding the pathogenicity of the synonymous variant c.5097 C > T (p.Tyr1699Tyr), based on the prediction of a potential exonic splicing enhancers (ESE) disruption by the Human Splicing Finder tool (51). This hypothesis was ruled out as mRNA studies on fibroblasts were not in favour of abnormal splicing. The median systemic score of patients with FBN1 mutations or deletions was above 7, whereas the median systemic score of patients without FBN1 mutations or deletions was below 7, but the results were not significantly different $(8.1 \pm 4.1 \mathrm{vs}$ $6.7 \pm 2.9)$. 
Table 1. Description of the population and results obtained in the total cohort, and depending on the classification of patients

\begin{tabular}{|c|c|c|c|}
\hline & $\begin{array}{l}\text { Group } 1 \text { Isolated } \mathrm{MH} \\
\text { and ID } n=80\end{array}$ & $\begin{array}{l}\text { Group } 2 \mathrm{MH}, \mathrm{ID} \text { and } \\
\text { another MFS } \\
\text { feature }^{\mathrm{a}} n=20\end{array}$ & $\begin{array}{c}\text { Overall series } \\
n=100\end{array}$ \\
\hline \multicolumn{4}{|l|}{ Clinical characteristics } \\
\hline Sex ratio $(n=100)$ & 2.8 & 1.5 & 2.4 \\
\hline Mean age $\pm \operatorname{SD}(n=100)$ & $18.4 \pm 7.8$ & $21.8 \pm 11.1$ & $19.1 \pm 8.6$ \\
\hline \multicolumn{4}{|l|}{ Cardiovascular } \\
\hline $\operatorname{TAA}(n=94)$ & $0 / 74(0 \%)$ & $10 / 20(50 \%)$ & $11 / 94(10 \%)$ \\
\hline Mitral valve prolapse $(n=94)$ & $0 / 74(0 \%)$ & $11 / 20(55 \%)$ & $12 / 94(12 \%)$ \\
\hline Other valvular abnormalities $(n=94)$ & $6 / 74(8 \%)$ & $12 / 20(60 \%)$ & 19/94 (19\%) \\
\hline \multicolumn{4}{|l|}{ Eye } \\
\hline Ectopia lentis $(n=92)$ & $0 / 73(0 \%)$ & 2/19 (10\%) & $2 / 92(2 \%)$ \\
\hline Myopia $(n=92)$ & $20 / 73(27 \%)$ & $3 / 19(16 \%)$ & $23 / 92(25 \%)$ \\
\hline $\begin{array}{l}\text { Other eye abnormality (strabismus, astigmatism, } \\
\text { hypermetropia, and nystagmus) }(n=79)\end{array}$ & $46 / 62(74 \%)$ & $8 / 17(47 \%)$ & $54 / 79(68 \%)$ \\
\hline \multicolumn{4}{|l|}{ Skeleton } \\
\hline Long and thin habitus $(n=99)$ & $76 / 80(95 \%)$ & 16/19 (84\%) & $92 / 99(93 \%)$ \\
\hline Arachnodactyly $(n=98)$ & $61 / 79(77 \%)$ & $13 / 19(68 \%)$ & $74 / 98(75 \%)$ \\
\hline Dolichostenomelia $(n=96)$ & $51 / 78(65 \%)$ & 14/18 (78\%) & $65 / 96(68 \%)$ \\
\hline Scoliosis $(n=99)$ & $44 / 80(55 \%)$ & $12 / 19(63 \%)$ & $56 / 99(56 \%)$ \\
\hline Pectus abnormalities $(n=100)$ & $38 / 80(48 \%)$ & $15 / 20(75 \%)$ & $53 / 100(53 \%)$ \\
\hline Joint laxity $(n=99)$ & $39 / 80(49 \%)$ & $8 / 19(42 \%)$ & $47 / 99(47 \%)$ \\
\hline Flat feet $(n=98)$ & $35 / 79(44 \%)$ & $8 / 19(42 \%)$ & $43 / 98$ (44\%) \\
\hline Limitation of extension of the elbow $(n=97)$ & $16 / 78(20 \%)$ & $1 / 19(5 \%)$ & $17 / 97(17 \%)$ \\
\hline Camptodactyly $(n=91)$ & 10/74 (13\%) & $3 / 17$ (18\%) & $13 / 91(14 \%)$ \\
\hline \multicolumn{4}{|l|}{ Others } \\
\hline Striae $(n=98)$ & $13 / 79(16 \%)$ & $5 / 19(26 \%)$ & 18/98 (18\%) \\
\hline Translucent skin $(n=88)$ & $2 / 70(3 \%)$ & $2 / 18(11 \%)$ & $4 / 88(4 \%)$ \\
\hline \multicolumn{4}{|l|}{ Median systemic score } \\
\hline \multicolumn{4}{|l|}{ Cerebral and cognitive } \\
\hline \multicolumn{4}{|l|}{ Degree of ID $(n=95)^{b}$} \\
\hline - Mild ID & 13/76 (17\%) & $4 / 19(21 \%)$ & $17 / 95$ (18\%) \\
\hline - Moderate ID & $43 / 76(56 \%)$ & $13 / 19(68 \%)$ & $56 / 95$ (59\%) \\
\hline - Severe ID & $20 / 76(26 \%)$ & $2 / 19(10 \%)$ & $22 / 95$ (23\%) \\
\hline $\begin{array}{l}\text { Behavioural abnormalities (including anxiety, } \\
\text { hyperactivity, psychotic troubles, and ASD) } \\
(n=98)\end{array}$ & $56 / 79(71 \%)$ & $13 / 19(68 \%)$ & $69 / 98$ (70\%) \\
\hline Epilepsy $(n=95)$ & $28 / 77(36 \%)$ & $5 / 18(28 \%)$ & $33 / 95(35 \%)$ \\
\hline Abnormal MRI $(n=45)^{\mathrm{C}}$ & $10 / 40(25 \%)$ & $3 / 6(50 \%)$ & $13 / 45(29 \%)$ \\
\hline \multicolumn{4}{|l|}{ Molecular and cytogenetic results $(n=100)$} \\
\hline Submicroscopic chromosome rearrangements & $11 / 80(14 \%)^{d}$ & $5 / 20(25 \%)^{d}$ & $16 / 100(16 \%)$ \\
\hline FBN1 & $2 / 80(2 \%)^{d}$ & $3 / 20(15 \%)^{d}$ & $5 / 100(5 \%)$ \\
\hline TGFBR1, TGFBR2 & $0 / 80(0 \%)$ & $0 / 20(0 \%)$ & 0/100 (0\%) \\
\hline MED12 & $1 / 80(1 \%)$ & 0/20 (0.0\%) & $1 / 100(1 \%)$ \\
\hline UPF3B, ZDHHC9 & $0 / 80(0 \%)$ & $0 / 20(0 \%)$ & $0 / 100(0 \%)$ \\
\hline \multicolumn{4}{|l|}{$X$-inactivation bias in females } \\
\hline - $>85 \%$ skewing & $28 / 80(35 \%)$ & 0/20 (0\%) & $28 / 100(28 \%)$ \\
\hline - >95\% skewing & $1 / 80(1.2 \%)^{e}$ & $0 / 20(0 \%)$ & $1 / 100(1 \%)$ \\
\hline Total & $14 / 80(18 \%)$ & $6 / 20(30 \%)^{d}$ & $20 / 100(20 \%)$ \\
\hline
\end{tabular}

ASD, autism spectrum disorder; ID, intellectual deficiency; MFS, Marfan syndrome; MH, marfanoid habitus; MRI, magnetic resonance imaging; TAA, thoracic aortic aneurysm.

ancluding TAA, ectopialentis, sinuous aorta and/or mitral valve prolapse.

bTwenty-three percent of patients had neuropsychological evaluation.

'Including absent corpus callosum, thin corpus callosum, corpus callosum dysgenesis, vermis hypoplasia, Arnold Chiari malformation, pituitary stalk interruption syndrome, asymmetric ventricles, cortical atrophy, hydrocephaly, arachnoidian cyst, enlarged Virchow Robin spaces, and enlarged citerna major.

dOne patient had both a FBN1 mutation and a chromosomal rearrangement.

ePatient P20 not carrying any cytogenetic nor molecular abnormality. 


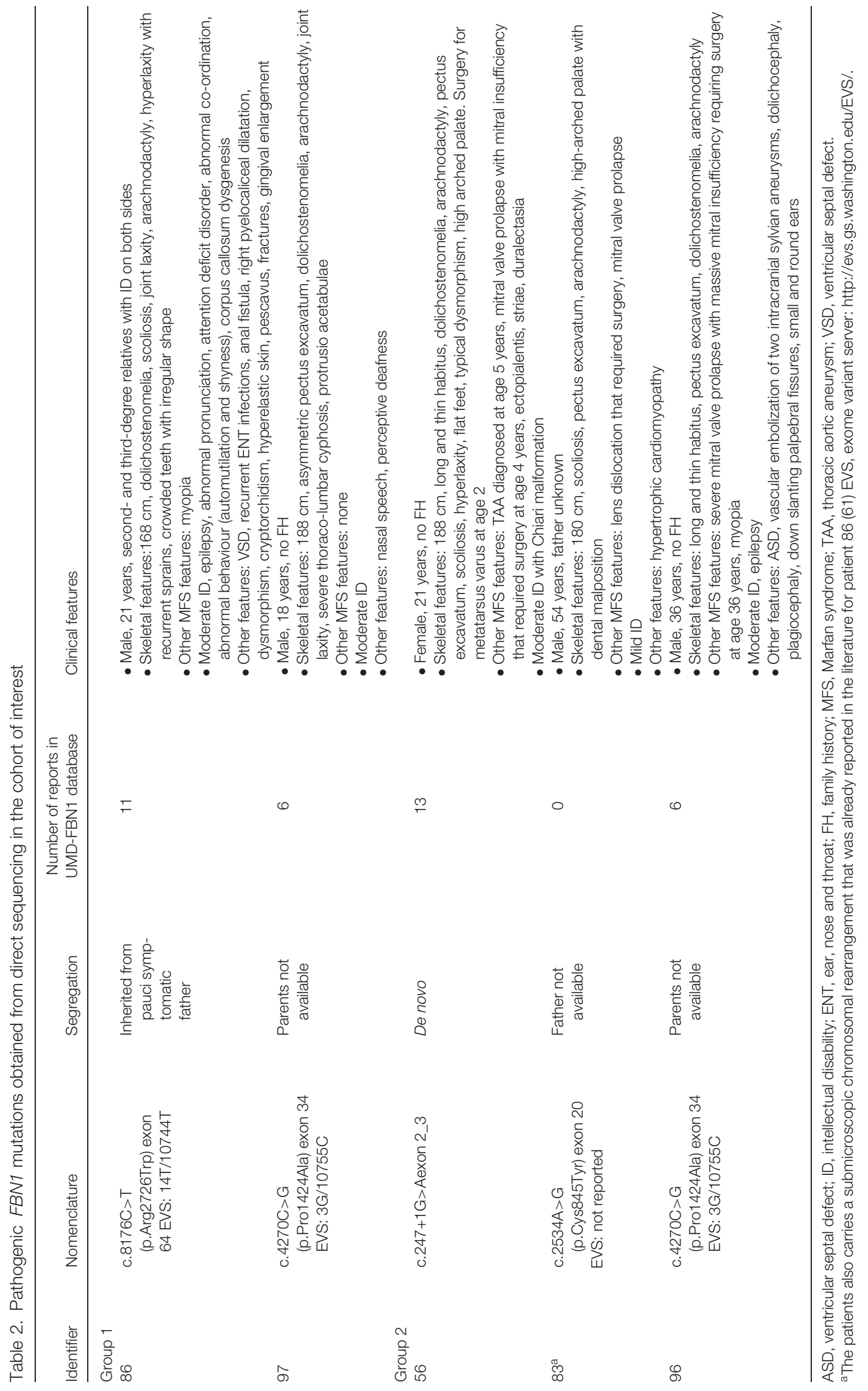


Table 3. Possibly pathogenic MED12 mutation obtained from direct sequencing in the cohort of interest

\begin{tabular}{|c|c|c|c|}
\hline Identifier & Nomenclature & Segregation & Clinical features \\
\hline 68 & $\begin{array}{l}\text { c. } 3884 G>A \\
\quad(p . A r g 1295 H i s)^{*} \\
\quad \text { exon } 28\end{array}$ & $\begin{array}{l}\text { Inherited from his } \\
\text { mother with mild ID, } \\
\text { and not found in the } \\
\text { two asymptomatic } \\
\text { brothers }\end{array}$ & $\begin{array}{l}\text { - Male, } 18 \text { years, mild phenotype in her mother (skeletal } \\
\text { features, mitral valve prolapse) } \\
\text { - Skeletal features: } 187 \mathrm{~cm} \text {, long and thin habitus, } \\
\text { pectus excavatum, joint laxity, malar hypoplasia, } \\
\text { down slanting palpebral fissures, teeth malposition } \\
\text { - Other MFS features : none } \\
\text { - Mild ID } \\
\text { - Other features: small and low-set ears, nasal speech, } \\
\text { bilateral ptosis }\end{array}$ \\
\hline
\end{tabular}

ID, intellectual disability; MFS, Marfan syndrome.

*Not reported in EVS (http://evs.gs.washington.edu/EVS/).

\section{TGFBR1 and TGFBR2 sequencing analysis}

Neither pathogenic mutations nor known variants were found in the TGFBRl gene. One missense and three synonymous variants were found in the coding sequence of the TGFBR2 gene. For three of them, their presence in an asymptomatic parent combined with database predictions were in favour of a polymorphism (Table S2). The c.1039C > T (p.Leu347Leu) variant was found to be de novo. On the basis of the prediction of a potential ESE disruption by the Human Splicing Finder tool (51), mRNA studies on lymphocytes were performed but the results were not in favour of abnormal splicing.

\section{MED12, UPF3B, and ZDHHC9 sequencing analysis}

One possibly pathogenic MED12 mutation was found (c.3884G > A, p.Arg1295His) in patient 68 (Table 3). The use of different databases gave opposite results, databases against the pathogenicity, taking into account the fact that a histidine is present at this position in another gene of the MED family. However, this amino acid is highly conserved across species (Fig. S1), and was not found in 200 male controls tested in the laboratory, or in the 1000 Genomes Project Consortium or in the EVS database (http://evs.gs.washington.edu/EVS/). Segregation in the family showed that the variant was inherited from the mother, who had a milder phenotype, which could be compatible with an X-linked inheritance, and was absent in the two healthy brothers. Additional functional studies should be performed in order to arrive at a definitive conclusion.

Table S2 summarizes the likely non-pathogenic variants found in this cohort. The c.3692-22A $>$ C MED12 variant was predicted to break the potential branch point (tccetAt, -22 position in the intron) according to the in silico splice site analysis program Human Splicing Finder (HSF) (51), but this hypothesis could not be confirmed by normal mRNA studies.

\section{X-inactivation studies}

An X-inactivation bias $>85 \%$ was found in seven females of group $1(7 / 20,35 \%)$, but absent in both other groups. When considering X-inactivation bias $>95 \%$, only one female was concerned.
Targeted array-CGH

Among the 100 patients, 84 displayed normal results, with no copy number variants (CNVs) or only the presence of benign CNVs. For 16 patients, genomic imbalances were detected ranging from $500 \mathrm{~kb}$ to $11.6 \mathrm{Mb}$, (i) ten deletions, including one deletion $15 \mathrm{q} 21.1 \mathrm{q} 21.3$ encompassing the FBNI gene; (ii) five duplications; and (iii) one patient with an unbalanced translocation (Table 4). The overviews of copy number changes of all patients along the whole genome are shown in Fig. 1. Two patients had both chromosomal rearrangements and a pathogenic FBN1 mutation. Five patients had a known microdeletional syndrome (3q29, 15q13.2q13.3 and 17q12 microdeletions, $15 \mathrm{q} 11.2$ and 16 p11.2 microduplications).

\section{Discussion}

The systematic screening of genes that may be involved in $\mathrm{MH}$ and ID in this study provides useful information regarding the work-up necessary in such patients. From a study of 100 patients, we showed that: (i) submicroscopic rearrangements are the most prevalent abnormalities, (ii) the presence of ID should not rule out the possibility of an FBN1 mutation; (iii) the association of two pathogenic abnormalities was possible, which means that extreme caution must be exercised when considering relating the overall phenotype to a given anomaly, unless additional data become available in the literature; (iv) the X-linked $M E D 12, Z D H H C 9$ and UPF3B genes are not major genes for $\mathrm{MH}$ and ID, although a skewed sex ratio in favour of males was found.

Submicroscopic rearrangements were identified in $16 / 100$ patients. This percentage is in the range of the overall detection rate of genomic imbalances by array-CGH in patients with ID and/or developmental delay (52). Retrospectively, the use of targeted custom oligonucleotide array-CGH did not permit the identification of intragenic rearrangement in the genes of interest. The chromosomal imbalances identified were all different, strengthening the hypothesis that high genetic heterogeneity exists in this phenotype. For each abnormality, we tried to determine if there was evidence that the rearrangement might explain the $\mathrm{MH}$, and 


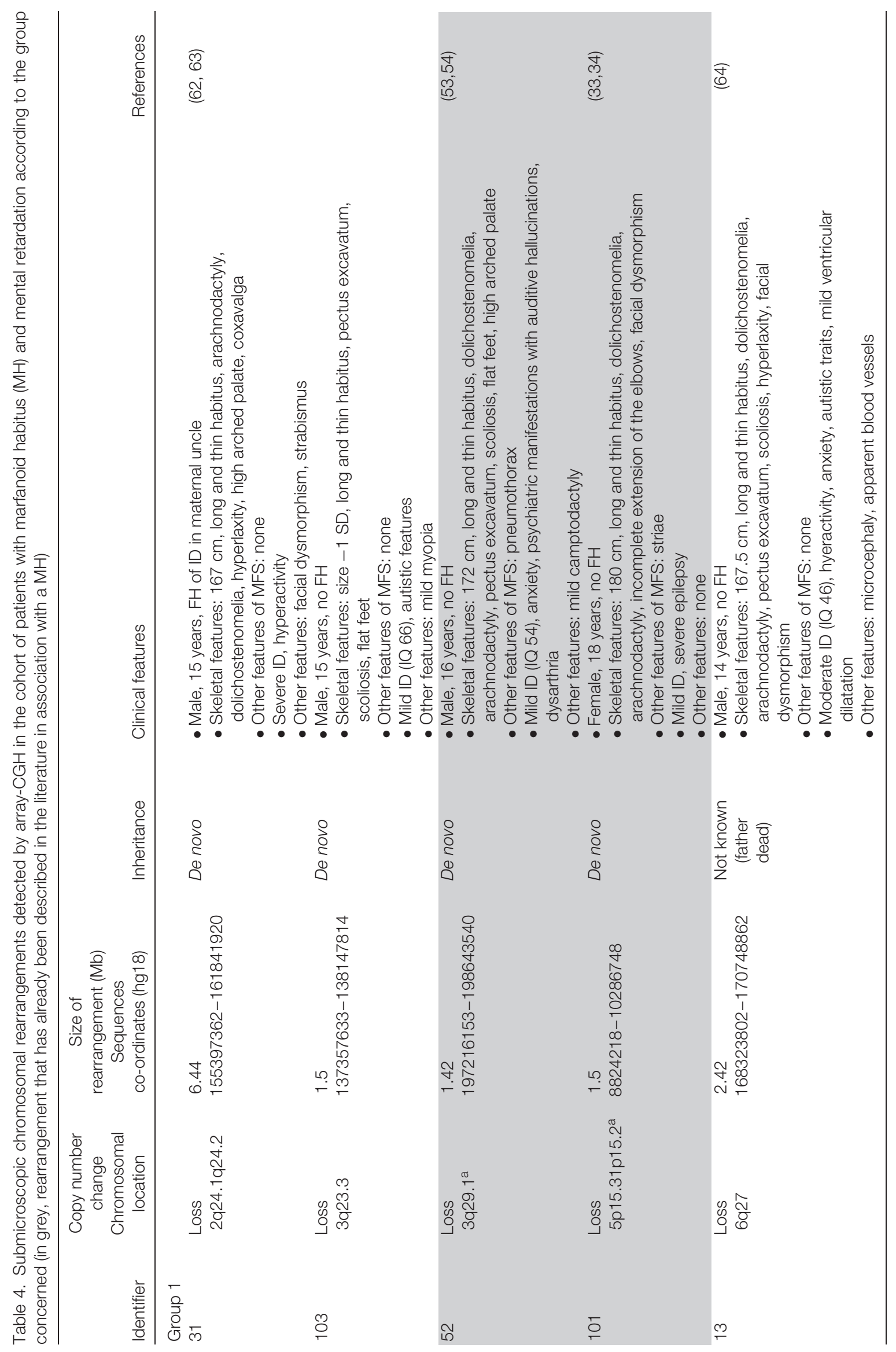




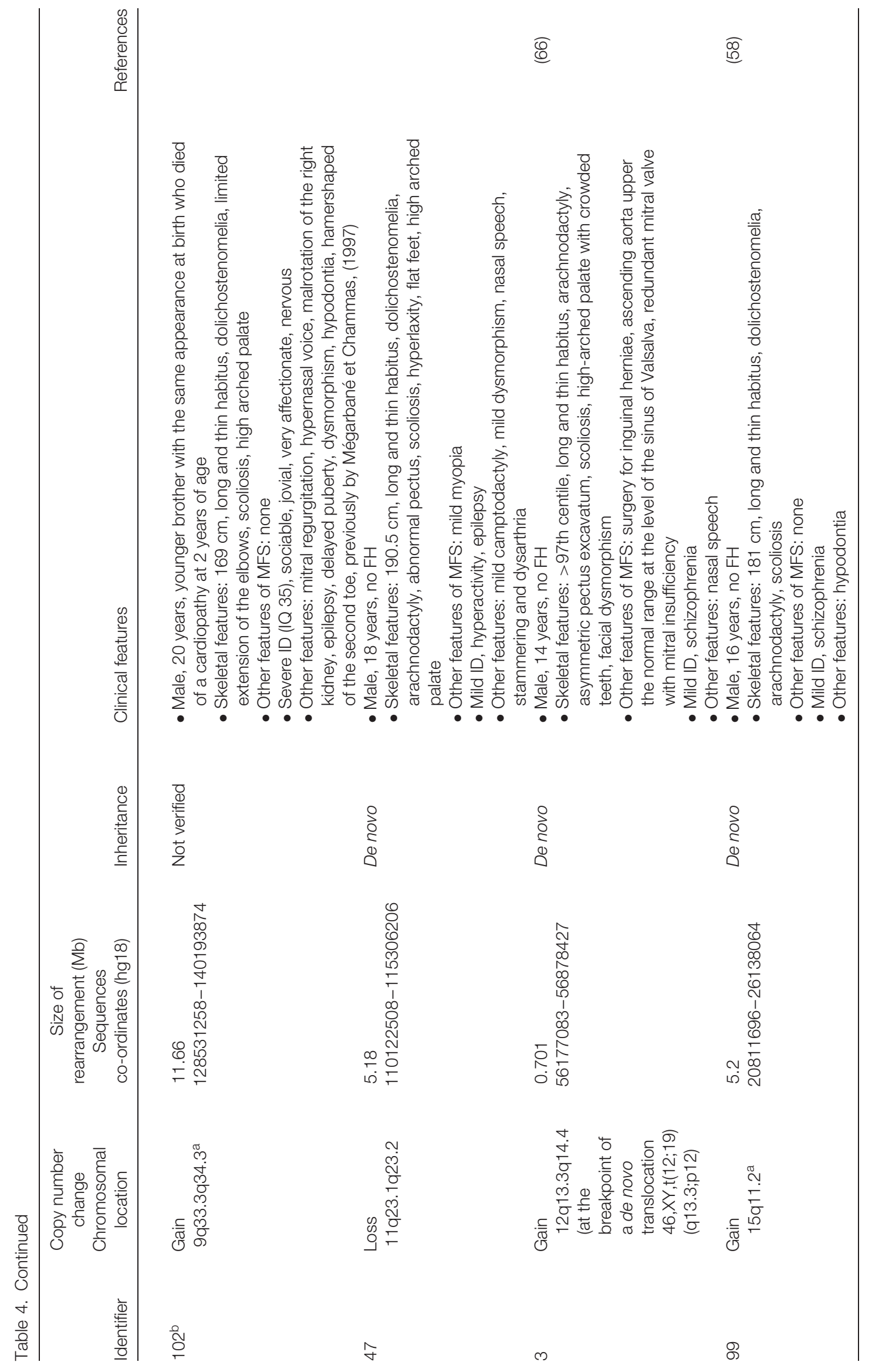




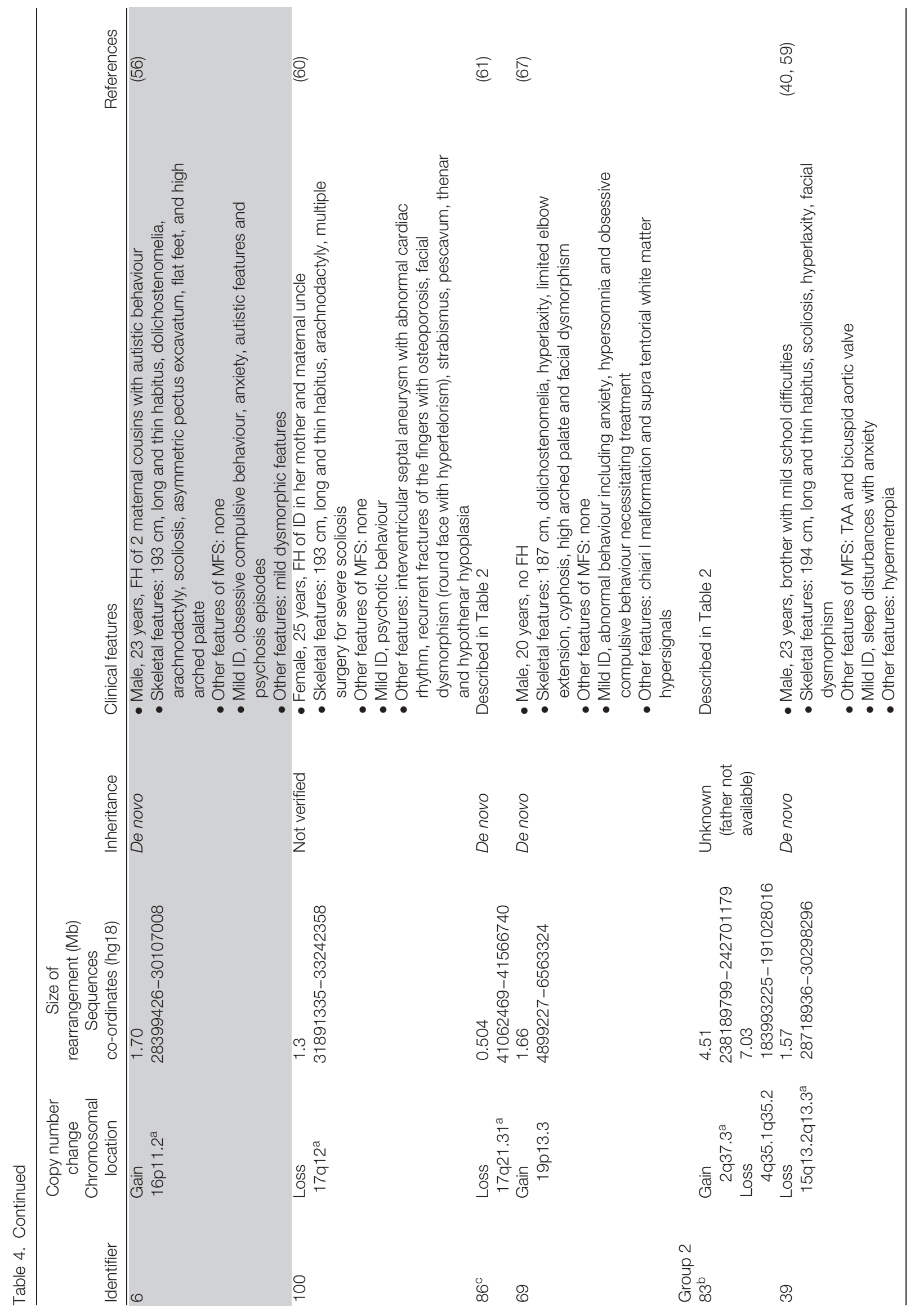




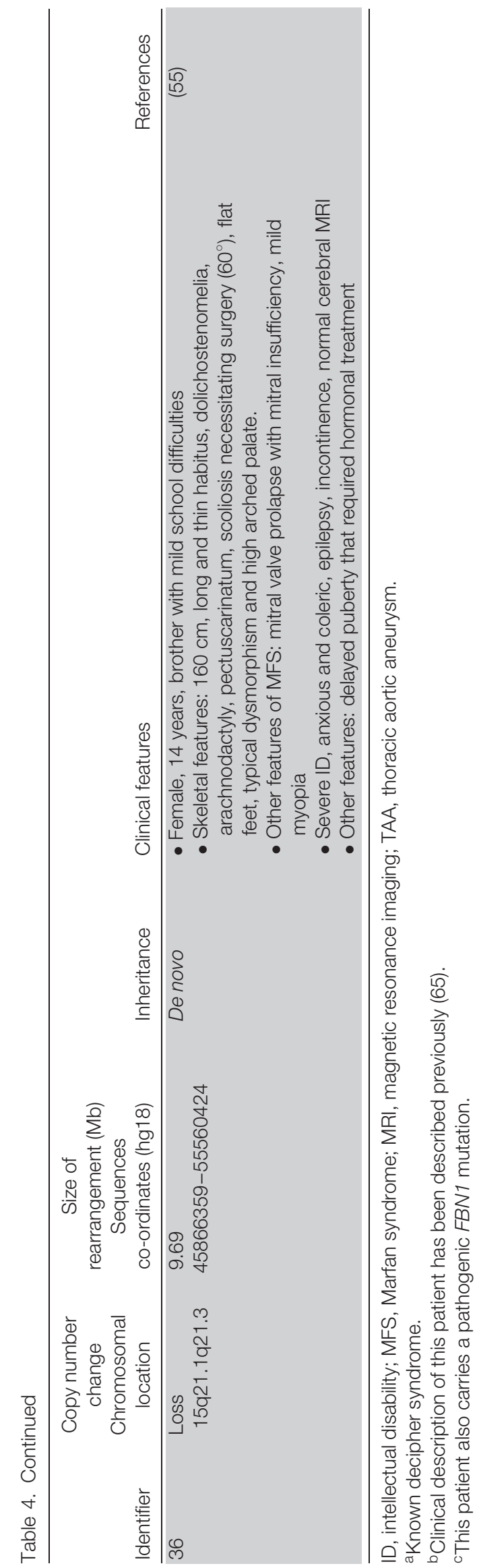

if the results could provide some information regarding the genes responsible for MH. In our series, the presence of a marfanoid phenotype was recurrent in 4/16 rearrangements, including the 3q29 microdeletion $(53,54)$, the 5p15.31p15.2 microdeletion $(33,34)$, the 15q21.1q21.3 microdeletion (55) and the 16p11.2 microduplication (56) (Table 4). Except for the FBN1 gene located in the $15 \mathrm{q} 21.1 \mathrm{q} 21.3$ microdeletion, none of the other rearrangements comprised a good candidate gene for the $\mathrm{MH}$. The recurrent de novo $3 \mathrm{q} 29$ microdeletion had a commonly deleted region of 1.6 $\mathrm{Mb}$, most likely secondary to non-allelic homologous recombination. Besides mild/moderate ID and a long, narrow face, chest-wall deformity has been described in $3 / 15$ patients, long, tapering fingers in $3 / 15$ patients, and ligamentous hyperlaxity in $1 / 15$ patient $(53,54)$. Of note, our patient had a more generalized $\mathrm{MH}$ and pneumothorax, which can be part of the MFS spectrum. Some patients with the 5pter microdeletion and with various marfanoid features in adolescence have already been described $(33,34)$. Unfortunately, previous patients were not studied using high resolution techniques. It was therefore not possible to determine the smallest region of overlap. Finally, it is highly probable that the phenotype found in the patient with chromosome 16p11.2 duplication could be fully explained by the cytogenetic abnormality as it has been recently shown that it was the countertype of patients presenting with chromosome $16 \mathrm{p} 11.2$ microdeletion with obesity and a wide range of behavioural abnormalities (57).

Conversely, we have data to conclude that the rearrangements in five patients were certainly responsible for ID but cannot explain the MH. Four of them are well-known frequent genomic rearrangements, comprising the 15q11.2 microduplication including $U B E 3 A / S N R P N(58)$, the $15 \mathrm{q} 13.3$ microdeletion including CHRNA7 (59), the 17q12 microdeletion (60) and finally the $17 \mathrm{q} 21.31$ microdeletion including $M A P T$ (61), and manifestations of MFS have never been described in large series. The best argument against the causality of the $17 \mathrm{q} 21.31$ microdeletion in $\mathrm{MH}$ is that we identified in the same patient a concomitant pathogenic FBN1 mutation. Similar conclusions can be drawn for the patient with an unbalanced translocation responsible for a $2 \mathrm{q} 37.3$ duplication and a 4q35.1q35.2 deletion, since the patient also carried a pathogenic FBN1 mutation. These observations especially emphasize the importance of a systematic screening approach for accurate genetic counselling and clinical follow-up. Unfortunately, no conclusion can be drawn for the other rearrangements.

The second take home message from this study is that the presence of ID should not rule out the diagnosis of MFS with its aortic risk, in a patient with MH. Indeed, $6 \%$ of our patients had a FBN1 mutation or a rearrangement involving $F B N 1$, i.e. $35 \%$ of the abnormalities found in the study. This conclusion is of importance as approximately a third of the patients were not screened by echocardiography prior to the study. When an FBN1 mutation was found, we have data showing that ID could be attributable to a different 


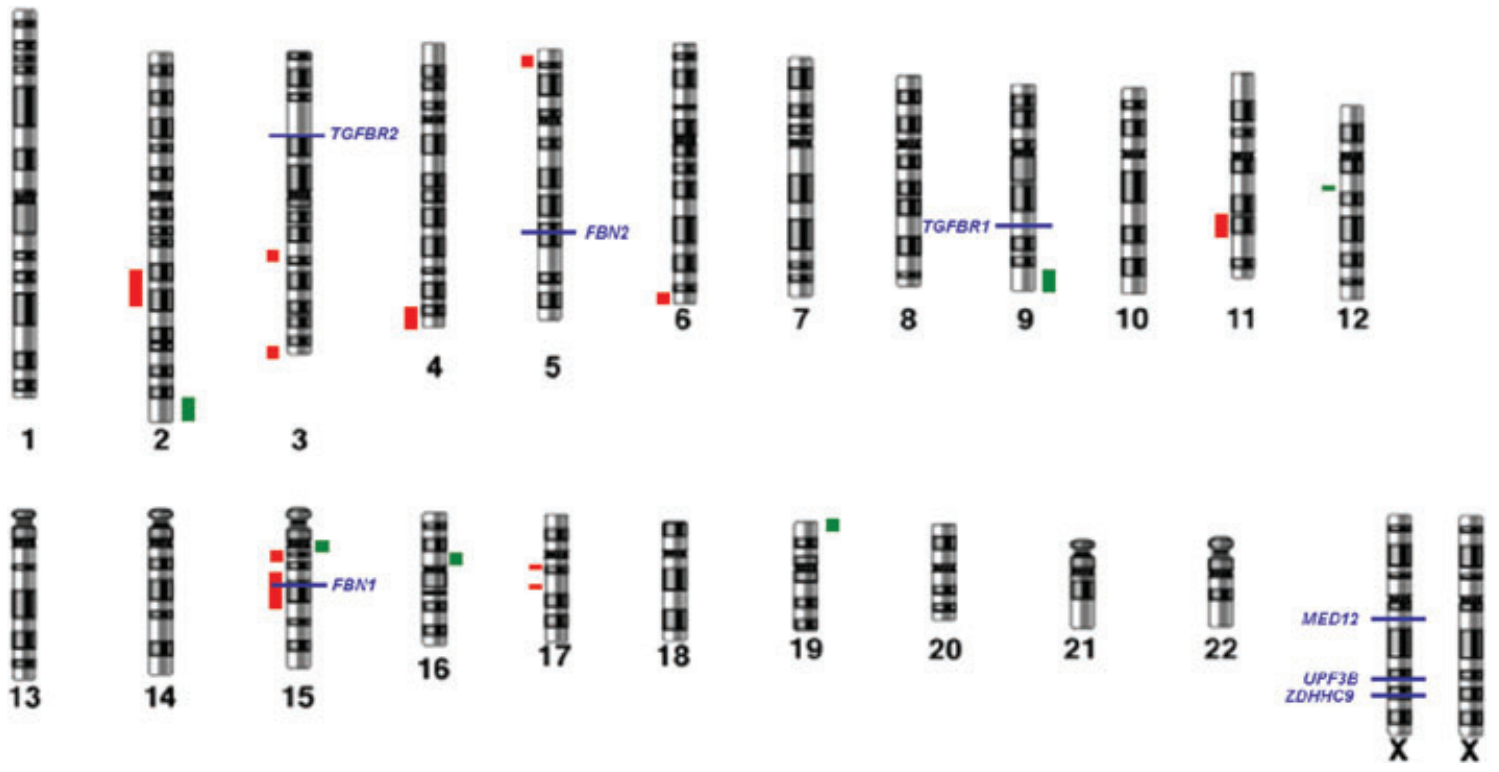

Fig. 1. Whole genome of the 16 abnormalities detected by custom array-CGH and map of targeted genes. DNA copy number losses and gains are highlighted in red and green, respectively, at the left and right, respectively, along the chromosome location.

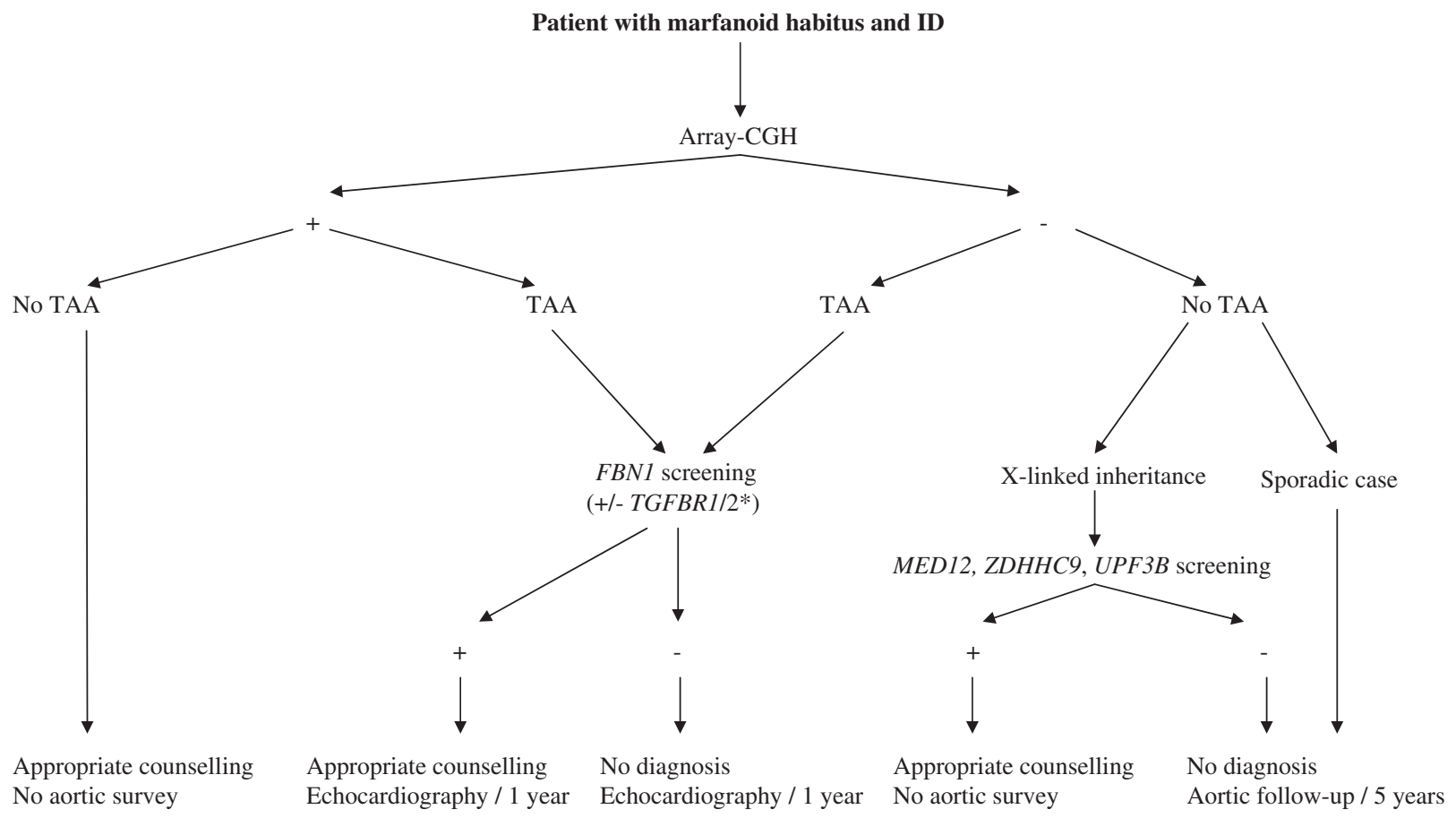

Fig. 2. Flow chart for the diagnosis of patients with MH and ID. TAA, thoracic aortic aneurysm. *The list of genes to be tested will lengthen as new syndromic TAA genes are identified.

cause, since two of the patients also had a chromosomal micro-rearrangement that explained the ID. Also, a large study of patients with MFS did not reveal an increased risk of ID (7). Given the very high allelic heterogeneity of the FBN1 gene, it was surprising to find the same mutation (c.4270C $>$ G, p.Pro1424Ala) in two unrelated patients of the study. However, six additional patients with the same mutation and with no ID were reported in the UMD-FBN1 database. The majority of FBN1 mutations/rearrangements was found in patients with TAA, ectopia lentis and/or mitral valve prolapse (four out of five were from group 2), but only skeletal manifestations were diagnosed at 22 years of age (patient 97, Table 2), confirming the high clinical variability of patients with $F B N 1$ mutations, who can present with isolated skeletal features (47).

By combining all these data it was possible to create a flow chart (Fig. 2) with the following recommendation: 
echocardiography and eye examination should be systematically performed in patients with $\mathrm{MH}$ and ID. If TAA or ectopia lentis is found, FBNI screening is warranted for genetic counselling and follow-up. The systemic score in patients with an FBNI mutation did not appear to be significantly different from that in other patients of the cohort. If the echocardiography and eye examination are normal, they should be performed at least every 5 years, to take into account the features that evolve with time.

The third answer from this study is that the three $\mathrm{X}$-linked genes found in association with LFS are not major genes in this clinical population, at least in sporadic patients. Indeed, only one probably pathogenic MED12 mutation (c.3884G $>$ A, p.Arg1295His) was identified in our cohort of 100 patients. However, very few familial cases were included, and we therefore cannot draw any conclusions about the frequency of MED12 involvement in cases with $\mathrm{X}$-linked inheritance. Nevertheless, the role of other X-linked genes appears probable because there was an obvious skewed sex ratio in favour of males in our cohort of patients.

Finally, no molecular or cytogenetic abnormalities were found in $80 \%$ of the patients ( $82 \%$ in group 1 and $70 \%$ in group 2). Chromosomal micro-rearrangements found in this study could point to new candidate regions to be studied to identify new genes responsible for the phenotype. Further studies with next-generation sequencing technology such as the exome approach using a trio strategy will hopefully help in the diagnosis of such patients. In particular, a distinct entity which associates TAA and intellectual deficiency may exist because no FBN1 mutation was found in the majority of the patients. Besides to the hypothesis that more loci with genes are yet to be discovered, an alternative explanation would be that $\mathrm{MH}$ is a relatively nonspecific feature of patient with ID. Future studies on the subject would be useful to know if a diagnostician should give importance or not on the marfanoid findings in association to ID, given that it can be a common genetic problem in the population.

In conclusion, this collaborative work suggests a practical diagnostic pathway resulting in a better clinical differentiation, and providing a basis for more effective management and appropriate genetic counselling for families with $\mathrm{MH}$ and ID.

\section{Supporting Information}

The following Supporting information is available for this article:

Fig S1. Interspecies conservation of the amino acid concerned by the MED12 missense mutation in patient 68 .

Table S1. Candidate genes with numbers of clones added to the custom array-CGH design.

Table S2. Non-pathogenic variant obtained from direct sequencing of the FBN1, TGFBR1, TGFBR2, MED12,UPF3B and ZDHHC9 in the cohort of interest.

Additional Supporting information may be found in the online version of this article.

\section{Acknowledgements}

The authors thank the French Ministry of Health (PHRC national 2008) as well as the Regional Council of Burgundy for their financial help of this project.

\section{References}

1. De Paepe A, Devereux RB, Dietz HC, Hennekam RC, Pyeritz RE. Revised diagnostic criteria for the Marfan syndrome. Am J Med Genet 1996: 62: 417-426.

2. Faivre L, Collod-Beroud G, Ades L et al. The new Ghent criteria for Marfan syndrome: what do they change? Clin Genet 2012: 81: 433-442.

3. Loeys BL, Dietz HC, Braverman AC et al. The revised Ghent nosology for the Marfan syndrome. J Med Genet 2010: 47: 476-485.

4. Faivre L, Collod-Beroud G, Loeys BL et al. Effect of mutation type and location on clinical outcome in 1,013 probands with Marfan syndrome or related phenotypes and FBN1 mutations: an international study. Am J Hum Genet 2007: 81: 454-466.

5. Faivre L, Collod-Beroud G, Child A et al. Contribution of molecular analyses in diagnosing Marfan syndrome and type I fibrillinopathies: an international study of 1009 probands. J Med Genet 2008: 45: 384-390.

6. Faivre L, Collod-Beroud G, Callewaert B et al. Pathogenic FBN1 mutations in 146 adults not meeting clinical diagnostic criteria for Marfan syndrome: further delineation of type 1 fibrillinopathies and focus on patients with an isolated major criterion. Am J Med Genet A 2009: 149A: 854-860.

7. Faivre L, Masurel-Paulet A, Collod-Beroud G et al. Clinical and molecular study of 320 children with Marfan syndrome and related type I fibrillinopathies in a series of 1009 probands with pathogenic FBN1 mutations. Pediatrics 2009: 123: 391-398.

8. Stheneur C, Collod-Beroud G, Faivre L et al. Identification of 23 TGFBR2 and 6 TGFBR1 gene mutations and genotype-phenotype investigations in 457 patients with Marfan syndrome type I and II, Loeys-Dietz syndrome and related disorders. Hum Mutat 2008: 29: E284-E295.

9. Heikura U, Taanila A, Olsen P et al. Temporal changes in incidence and prevalence of intellectual disability between two birth cohorts in Northern Finland. Am J Ment Retard 2003: 108: 19-31.

10. Fryns JP, Buttiens M. X-linked mental retardation with marfanoid habitus. Am J Med Genet 1987: 28: 267-274.

11. Lujan JE, Carlin ME, Lubs HA. A form of X-linked mental retardation with marfanoid habitus. Am J Med Genet 1984: 17: 311-322.

12. Fryns JP, Van Den Berghe H. X-linked mental retardation with Marfanoid habitus: a changing phenotype with age? Genet Couns 1991: 2: 241-244.

13. Van Buggenhout G, Fryns JP. Lujan-Fryns syndrome (mental retardation, X-linked, marfanoid habitus). Orphanet J Rare Dis 2006: 1: 26.

14. Fryns JP. X-linked mental retardation with marfanoid habitus. Am J Med Genet 1991: 38: 233.

15. Gurrieri F, Neri G. A girl with the Lujan-Fryns syndrome. Am J Med Genet 1991: 38: 290-291.

16. Lerma-Carrillo I, Molina JD, Cuevas-Duran T et al. Psychopathology in the Lujan-Fryns syndrome: report of two patients and review. Am J Med Genet A 2006: 140: 2807-2811.

17. Wittine LM, Josephson KD, Williams MS. Aortic root dilation in apparent Lujan-Fryns syndrome. Am J Med Genet 1999: 86: 405-409.

18. Raymond FL, Tarpey PS, Edkins S et al. Mutations in ZDHHC9, which encodes a palmitoyltransferase of NRAS and HRAS, cause X-linked mental retardation associated with a Marfanoid habitus. Am J Hum Genet 2007: 80: 982-987.

19. Schwartz CE, Tarpey PS, Lubs HA et al. The original Lujan syndrome family has a novel missense mutation (p.N1007S) in the MED12 gene. J Med Genet 2007: 44: 472-477.

20. Tarpey PS, Raymond FL, Nguyen LS et al. Mutations in UPF3B, a member of the nonsense-mediated mRNA decay complex, cause syndromic and nonsyndromic mental retardation. Nat Genet 2007: 39: 1127-1133.

21. Blazek E, Mittler G, Meisterernst M. The mediator of RNA polymerase II. Chromosoma 2005: 113: 399-408. 
22. Hong SK, Haldin CE, Lawson ND et al. The zebrafish kohtalo/trap230 gene is required for the development of the brain, neural crest, and pronephric kidney. Proc Natl Acad Sci U S A 2005: 102: 18473-18478.

23. Swarthout JT, Lobo S, Farh L et al. DHHC9 and GCP16 constitute a human protein fatty acyltransferase with specificity for $\mathrm{H}$ - and N-Ras. J Biol Chem 2005: 280: 31141-31148.

24. Conti E, Izaurralde E. Nonsense-mediated mRNA decay: molecular insights and mechanistic variations across species. Curr Opin Cell Biol 2005: 17: 316-325.

25. Risheg H, Graham JM Jr, Clark RD et al. A recurrent mutation in MED12 leading to R961W causes Opitz-Kaveggia syndrome. Nat Genet 2007: 39: 451-453.

26. Greally MT, Carey JC, Milewicz DM et al. Shprintzen-Goldberg syndrome: a clinical analysis. Am J Med Genet 1998: 76: 202-212.

27. Robinson PN, Neumann LM, Demuth S et al. Shprintzen-Goldberg syndrome: fourteen new patients and a clinical analysis. Am J Med Genet A 2005: 135: 251-262.

28. Kosaki K, Takahashi D, Udaka $\mathrm{T}$ et al. Molecular pathology of Shprintzen-Goldberg syndrome. Am J Med Genet A 2006: 140 104-108 author reply $109-110$.

29. Sood S, Eldadah ZA, Krause WL, McIntosh I, Dietz HC. Mutation in fibrillin-1 and the Marfanoid-craniosynostosis (Shprintzen-Goldberg) syndrome. Nat Genet 1996: 12: 209-211.

30. van Steensel MA, van Geel M, Parren LJ, Schrander-Stumpel CT, Marcus-Soekarman D. Shprintzen-Goldberg syndrome associated with a novel missense mutation in TGFBR2. Exp Dermatol 2008: 17: $362-365$.

31. Loeys BL, Chen J, Neptune ER et al. A syndrome of altered cardiovascular, craniofacial, neurocognitive and skeletal development caused by mutations in TGFBR1 or TGFBR2. Nat Genet 2005: 37: $275-281$

32. Ades LC, Sullivan K, Biggin A et al. FBN1, TGFBR1, and the Marfan-craniosynostosis/mental retardation disorders revisited. Am J Med Genet A 2006: 140: 1047-1058.

33. Stathopulu E, Ogilvie CM, Flinter FA. Terminal deletion of chromosome $5 \mathrm{p}$ in a patient with phenotypical features of Lujan-Fryns syndrome. Am J Med Genet A 2003: 119A: 363-366.

34. Zhang SZ, Tang YC, Dai FP, Niebuhr E. $5 p ; 12 q$ translocation with manifestations of cri du chat syndrome and Marfanoid arachnodactyly. Clin Genet 1990: 37: 153-157.

35. Sandhu HK, Sarkar M, Turner BM, Wassink TH, Philibert RA Polymorphism analysis of HOPA: a candidate gene for schizophrenia Am J Med Genet B Neuropsychiatr Genet 2003: 123B: 33-38.

36. Stheneur C, Oberkampf B, Chevallier B. Marfan syndrome: diagnostic criteria and molecular biology contribution. Arch Pediatr 2008: 15: 564-567.

37. Collod-Beroud G, Le Bourdelles S, Ades L et al. Update of the UMD-FBN1 mutation database and creation of an FBN1 polymorphism database. Hum Mutat 2003: 22: 199-208.

38. Frederic MY, Hamroun D, Faivre L et al. A new locus-specific database (LSDB) for mutations in the TGFBR2 gene: UMD-TGFBR2. Hum Mutat 2008: 29: 33-38.

39. Allen RC, Zoghbi HY, Moseley AB, Rosenblatt HM, Belmont JW. Methylation of HpaII and HhaI sites near the polymorphic CAG repeat in the human androgen-receptor gene correlates with $\mathrm{X}$ chromosome inactivation. Am J Hum Genet 1992: 51: 1229-1239.

40. Masurel-Paulet A, Andrieux J, Callier P et al. Delineation of $15 \mathrm{q} 13.3$ microdeletions. Clin Genet 2010: 78: 149-161.

41. Frederic MY, Lalande M, Boileau C et al. UMD-predictor, a new prediction tool for nucleotide substitution pathogenicity -- application to four genes: FBN1, FBN2, TGFBR1, and TGFBR2. Hum Mutat 2009: 30: $952-959$.

42. Arbustini E, Grasso M, Ansaldi S et al. Identification of sixty-two novel and twelve known FBN1 mutations in eighty-one unrelated probands with Marfan syndrome and other fibrillinopathies. Hum Mutat 2005 26: 494.

43. Biggin A, Holman K, Brett M, Bennetts B, Ades L. Detection of thirty novel FBN1 mutations in patients with Marfan syndrome or a related fibrillinopathy. Hum Mutat 2004: 23: 99.

44. Comeglio P, Evans AL, Brice GW, Child AH. Detection of six novel FBN1 mutations in British patients affected by Marfan syndrome. Hum Mutat 2001: 18: 251.
45. Comeglio P, Johnson P, Arno G et al. The importance of mutation detection in Marfan syndrome and Marfan-related disorders: report of 193 FBN1 mutations. Hum Mutat 2007: 28: 928.

46. Howarth R, Yearwood C, Harvey JF. Application of dHPLC for mutation detection of the fibrillin-1 gene for the diagnosis of Marfan syndrome in a National Health Service Laboratory. Genet Test 2007 11: $146-152$.

47. Milewicz DM, Grossfield J, Cao SN et al. A mutation in FBN1 disrupts profibrillin processing and results in isolated skeletal features of the Marfan syndrome. J Clin Invest 1995: 95: 2373-2378.

48. Buoni S, Zannolli R, Macucci F et al. The FBN1 (R2726W) mutation is not fully penetrant. Ann Hum Genet 2004: 68: 633-638.

49. Van Dijk FS, Hamel BC, Hilhorst-Hofstee Y et al. Compoundheterozygous Marfan syndrome. Eur J Med Genet 2009: 52: 1-5.

50. Tjeldhorn L, Rand-Hendriksen S, Gervin K et al. Rapid and efficient FBN1 mutation detection using automated sample preparation and direct sequencing as the primary strategy. Genet Test 2006: 10 $258-264$.

51. Desmet FO, Hamroun D, Lalande M et al. Human Splicing Finder: an online bioinformatics tool to predict splicing signals. Nucleic Acids Res 2009: 37: e67.

52. de Vries BB, Pfundt R, Leisink M et al. Diagnostic genome profiling in mental retardation. Am J Hum Genet 2005: 77: 606-616.

53. Ballif BC, Theisen A, Coppinger $\mathrm{J}$ et al. Expanding the clinica phenotype of the 3q29 microdeletion syndrome and characterization of the reciprocal microduplication. Mol Cytogenet 2008: 1: 8 .

54. Willatt L, Cox J, Barber J et al. 3q29 microdeletion syndrome: clinical and molecular characterization of a new syndrome. Am J Hum Genet 2005: 77: $154-160$.

55. Faivre L, Khau Van Kien $P$, Callier $P$ et al. De novo $15 q 21.1 q 21.2$ deletion identified through FBN1 MLPA and refined by $244 \mathrm{~K}$ array$\mathrm{CGH}$ in a female teenager with incomplete Marfan syndrome. Eur J Med Genet 2010: 53: 208-212.

56. Jacquemont S, Reymond A, Zufferey F et al. Mirror extreme BMI phenotypes associated with gene dosage at the chromosome 16p11.2 locus. Nature 2011: 478: 97-102.

57. Walters RG, Jacquemont $\mathrm{S}$, Valsesia A et al. A new highly penetrant form of obesity due to deletions on chromosome 16p11.2. Nature 2010 : 463: $671-675$

58. Kitsiou-Tzeli S, Tzetis M, Sofocleous $\mathrm{C}$ et al. De novo interstitial duplication of the 15q11.2-q14 PWS/AS region of maternal origin: clinical description, array $\mathrm{CGH}$ analysis, and review of the literature. Am J Med Genet A 2010: 152A: 1925-1932.

59. Sharp AJ, Mefford HC, Li K et al. A recurrent $15 q 13.3$ microdeletion syndrome associated with mental retardation and seizures. Nat Genet 2008: 40: 322-328.

60. Nagamani SC, Erez A, Shen J et al. Clinical spectrum associated with recurrent genomic rearrangements in chromosome 17q12. Eur J Hum Genet 2010: 18: 278-284.

61. Dubourg C, Sanlaville D, Doco-Fenzy M et al. Clinical and molecular characterization of $17 \mathrm{q} 21.31$ microdeletion syndrome in 14 French patients with mental retardation. Eur J Med Genet 2011: 54: 144-151.

62. Magri C, Piovani G, Pilotta A et al. De novo deletion of chromosome 2 q24.2 region in a mentally retarded boy with muscular hypotonia. Eur J Med Genet 2011: 54: 361-364.

63. Palumbo O, Palumbo $\mathrm{P}$, Palladino $\mathrm{T}$ et al. A novel deletion in $2 \mathrm{q} 24.1 \mathrm{q} 24.2$ in a girl with mental retardation and generalized hypotonia: a case report. Mol Cytogenet 2012: 5: 1.

64. Mosca AL, Callier P, Masurel-Paulet A et-al. Cytogenetic and array-CGH characterization of a $6 \mathrm{q} 27$ deletion in a patient with developmental delay and features of Ehlers-Danlos syndrome. Am J Med Genet A 2010: 152A: 1314-1317.

65. Megarbane A, Chammas C. Severe mental retardation with marfanoid habitus in a young Lebanese male. A diagnostic challenge. Genet Couns 1997: 8: 195-200.

66. Vermeesch JR, Syrrou M, Salden I et al. Mosaicism for duplication $12 \mathrm{q}(12 \mathrm{q} 13-->12 \mathrm{q} 21.2)$ accompanied by a pericentric inversion in a dysmorphic female infant. J Med Genet 2002: 39: e72.

67. Siggberg L, Olsen P, Nanto-Salonen K, Knuutila S. 19p13.3 aberrations are associated with dysmorphic features and deviant psychomotor development. Cytogenet Genome Res 2011: 132: 8-15. 